\title{
Soil Enzymes as Influenced by Pre and Post Emergence Herbicide in Sweet Corn Grown in Vertisols
}

\author{
R. K. Rathod, V. P. Bhalerao, P. B. Margal* and R. S. Thakare \\ Department of Soil Science and Agricultural Chemistry, College of Agriculture, \\ Dhule (Maharashtra), India \\ *Corresponding author
}

\section{A B S T R A C T}

Keywords

Dehydrogenase, Urease

\section{Article Info}

\section{Accepted:}

18 December 2020

Available Online:

10 January 2021
Field experiment was conducted at Department of Agronomy, College of Agriculture, Dhule during Kharif 2019 to study the effect of pre and post emergence herbicides on soil enzymes in sweet corn. The soil enzymes activity viz. dehydrogenase, urease was significantly influenced due to application of pre and post emergence herbicides. The per cent decrease in the dehydrogenase activity at harvest was $14.79 \%, 30.15 \%$ and 32.57 to $35.70 \%$ in weed free treatment (two hand weeding), weedy check $\left(\mathrm{T}_{1}\right)$ and treatments of pre and post emergence herbicides $\left(\mathrm{T}_{3}\right.$ to $\left.\mathrm{T}_{10}\right)$, respectively over the initial value of $19.8 \mu \mathrm{g}$ TPF $\mathrm{g}^{-1}$ soil $24 \mathrm{~h}^{-1}$. The per cent decrease in the urease activity was $4.39 \%, 13.56 \%$ and 17.02 to $17.88 \%$ in the weed free treatment (two hand weeding), weedy check $\left(\mathrm{T}_{1}\right)$ and treatments of pre and post emergence herbicides $\left(\mathrm{T}_{3}\right.$ to $\left.\mathrm{T}_{10}\right)$, respectively over the initial value of $28.9 \mathrm{mg} \mathrm{NH}_{4}-\mathrm{N} 100 \mathrm{~g} \mathrm{soil} \mathrm{h}^{-1}$.Application of tembotrione @ $120 \mathrm{~g} \mathrm{ha}^{-1}$ as post emergence herbicide $\left(\mathrm{T}_{9}\right)$ showed less adverse effect on soil dehydrogenase and urease activity at harvest than the other herbicides treatments.

\section{Introduction}

Sweet corn (Zea mays var. saccharata) also called as "sugar corn", "pole corn" or simply corn, is a variety of maize with high sugar content. In India, sweet corn is cultivated on very small area to meet the demands of many industries. The demand for eating roasted cobs in cities and towns is increasing day by day. Sweet corn is gaining popularity among the urban masses in terms of nutrition and health consciousness in India. Heavy weed infestation is one of the major constraints that limit the productivity of sweet corn crop.
Wider spacing and slow growing nature of the crop during the first 3-4 weeks provide enough opportunity for weeds to invade and offer severe competition resulting in 30-100 $\%$ yield reduction (Dey et al., 2017). Weeds emerge fast and grow rapidly competing with the crop for growth viz., nutrients, moisture, sunlight and space during entire vegetative and early reproductive stages of sweet corn.

In the modern era of urbanization, labour component in agriculture is becoming scarce, not available at time and prohibitive cost. Chemical weed control is a better supplement 
to conventional methods and forms an integral part of the modern crop production. Herbicides are toxic agrochemicals, which have being used to control the weeds in the agricultural farms and gardens. These herbicides are rampantly used to some extent, by farmers without considering the long or short term effects in soil medium. It is evident that most of these herbicides may cause the reduction of sensitive populations of certain groups of biota in soil medium.

The effect of glyphosate, paraquat, trifluralin and atrazine on soil enzymes activities of dehydrogenase, phosphatase and urease was studied by Davies and Greaves, (1981). They reported that when recommended doses were used, enzymes activities were not affected by the herbicides. The wide range of soils used with greatly differing enzyme activities, and varying assay conditions like temperature, $\mathrm{pH}$, and substrate concentrations were responsible for contradictory results on effect of herbicides on soil. So, serious attempts should be made, possibly by judging the effects against those natural stresses or against the background of natural variation for assay of soil enzymes.

Dehydrogenase is the respiration enzyme presents in viable cells and reflects the total range of oxidative activity of soil microflora and may be a good indicator of microbial activity. Dehydrogenase significantly correlated with microbial population and soil organic matter. Optimum and balanced application of nutrients led to significant increase in dehydrogenase activity (Srinivasarao et al., 2018). The dehydrogenase catalyzes the biological oxidation and dehalogenation of a number of herbicides and other organic compounds (Beller et al., 1996).

Urease catalyses the hydrolysis of urea to $\mathrm{CO}_{2}$ and $\mathrm{NH}_{4}$. Higher organic matter level provide a more favourable environment for the accumulation of enzymes in the soil matrix, since soil organic constituent are thought to be important in forming stable complexes with free enzymes (Bansal et al., 2015).

Though lot of information is available concerning the influence of herbicide on soil micro flora and fauna, very little information is available concerning their effects on soil soil enzyme activity particularly those enzymes related with soil fertility. Keeping these fact in view, experiment was conducted to study the effect of pre and post emergence herbicides on soil enzymes in sweet corn.

\section{Materials and Methods}

Field experiment was conducted at Department of Agronomy, College of Agriculture, Dhule during Kharif 2019 to study the effect of pre and post emergence herbicides on soil enzymes in sweet corn. The experiment was laid out in randomized block design with ten treatments replicated three times. Treatments composed of $\mathrm{T}_{1}$ : weedy check, $\mathrm{T}_{2}$ : weed free (two hand weeding), $\mathrm{T}_{3}$ : atrazine @ $1000 \mathrm{~g} \mathrm{ha}^{-1}$ (PE) fb halosulfuron methyl @ $90 \mathrm{~g} \mathrm{ha}^{-1}(\mathrm{PoE}), \mathrm{T}_{4}$ : atrazine @ $1000 \mathrm{~g} \mathrm{ha}^{-1}$ (PE) fb 2,4 D ethyl ester @ 1000 $\mathrm{g} \mathrm{ha}^{-1}(\mathrm{PoE}), \mathrm{T}_{5}$ : pendimethalin @ $1000 \mathrm{~g} \mathrm{ha}^{-1}$ (PE) $f b$ halosulfuron-methyl @ $90 \mathrm{~g} \mathrm{ha}^{-1}$ (PoE), $\mathrm{T}_{6}$ : pendimethalin@1000 $\mathrm{g} \mathrm{ha}^{-1}(\mathrm{PE})$ $f b$ tembotrione @ $120 \mathrm{~g} \mathrm{ha}^{-1}(\mathrm{PoE}), \mathrm{T}_{7}$ : pendimethalin@1000 $\mathrm{g} \mathrm{ha}^{-1}$ (PE) fb 2,4 D ethyl ester @ $1000 \mathrm{~g} \mathrm{ha}{ }^{-1}(\mathrm{PoE}), \mathrm{T}_{8}$ : halosulfuron-methyl @ $90 \mathrm{~g} \mathrm{ha}^{-1}(\mathrm{PoE}), \mathrm{T}_{9}$ : tembotrione@120 g ha ${ }^{-1}(\mathrm{PoE})$ and $\mathrm{T}_{10}: 2,4$ D ethyl ester@1000 $\mathrm{g} \mathrm{ha}^{-1}(\mathrm{PoE})$. The pre emergence (PE) herbicides were applied on next day after sowing of sweet corn, however, the post emergence (PoE) hebicides were applied 30 days after sowing of sweet corn.

The soil of experimental site was medium black with the following chemical properties: 
pH 8. 01, electrical conductivity (EC) $0.32 \mathrm{dS}$ $\mathrm{m}^{-1}$, organic carbon $\left(5.60 \mathrm{~g} \mathrm{~kg}^{-1}\right)$, calcium carbonate $\left(49 \mathrm{~g} \mathrm{~kg}^{-1}\right)$, available $\mathrm{N}(202.34 \mathrm{~kg}$ $\mathrm{ha}^{-1}$ ), available (Olsen-P) P (17. $32 \mathrm{~kg} \mathrm{ha}^{-1}$ ), available $\left(\mathrm{NH}_{4} \mathrm{OAc}-\mathrm{K}\right) \mathrm{K}\left(402.25 \mathrm{~kg} \mathrm{ha}^{-1}\right)$, dehydrogenase (19. $18 \mu \mathrm{g}$ TPF g $\mathrm{g}^{-1}$ soil $24 \mathrm{~h}^{-1}$ ) and urease $\left(28.9 \mathrm{mg} \mathrm{NH}_{4}-\mathrm{N} 100 \mathrm{~g}^{-1} \mathrm{~h}^{-1}\right)$.

Representative moistened soil samples were collected from each plot before sowing, at 7 , 15, 21, 30 and 45 DAS as well as at harvest. Dehydrogenase activity was determined by spectrophotometric method (Casida et al., 1964). Urease activity was determined by titrimetric method (Tabatabai and Bremner 1972).

\section{Results and Discussion}

\section{Dehydrogenase activity}

The periodical dehydrogenase activity in soil was significantly influenced at 7, 15, 21, 30 and 45 days after application by pre and post emergence herbicides during the field experiment. The weed free (two hand weeding) treatment $\left(\mathrm{T}_{2}\right)$ recorded significantly higher dehydrogenase activity of 21. 61, 23. 34, 22. 74 and 21. $57 \mu \mathrm{g} \mathrm{TPF} \mathrm{g}{ }^{-1}$ soil $24 \mathrm{~h}^{-1}$ at 15,21 , 30 and 45 DAS, respectively, as compared to rest of the treatments. However, reduction (18. $93 \mu \mathrm{g}$ TPF $\mathrm{g}^{-1}$ soil $24 \mathrm{~h}^{-1}$ ) in dehydrogenase activity at 7 DAS was observed in $T_{2}$ treatment. The periodical dehydrogenase activity was increased by $12.46 \%$ over the initial value (19. $18 \mu \mathrm{g}$ TPF $\mathrm{g}^{-1}$ soil $24 \mathrm{~h}^{-1}$ ) at 45 DAS in $\mathrm{T}_{2}$ treatment. The periodical dehydrogenase activity in soil was decreased with advanced period of field experimentation in the treatment of weedy check $\left(\mathrm{T}_{1}\right)$ and the treatments of pre and post emergence herbicides application $\left(\mathrm{T}_{3}\right.$ to $\left.\mathrm{T}_{10}\right)$. The periodical dehydrogenase activity at 45 DAS in the treatment of weedy check $\left(\mathrm{T}_{1}\right)$ was 15 . $35 \mu \mathrm{g}$ TPF $\mathrm{g}^{-1}$ soil $24 \mathrm{~h}^{-1}$ with $19.96 \%$ reduction over the initial value (19. $18 \mu \mathrm{g}$ TPF $\mathrm{g}^{-1}$ soil $24 \mathrm{~h}^{-1}$ ). The periodical dehydrogenase activity at 45 DAS was ranged between 11. 74 to $12.81 \mu \mathrm{g}$ TPF $\mathrm{g}^{-1}$ soil $24 \mathrm{~h}^{-1}$ in the treatments of pre and post emergence herbicides application $\left(\mathrm{T}_{3}\right.$ to $\left.\mathrm{T}_{10}\right)$ with 33.21 to $38.79 \%$ reduction over the initial value.

The dehydrogenase activity was significantly higher (16. $87 \mu \mathrm{g}$ TPF $\mathrm{g}^{-1}$ soil $24 \mathrm{~h}^{-1}$ ) in the weed free treatment (two hand weeding) at harvest of sweet corn. It was followed by the treatment of weedy check $\left(\mathrm{T}_{1}\right)$, which recorded the dehydrogenase activity $13.83 \mu \mathrm{g}$ TPF $\mathrm{g}^{-1}$ soil $24 \mathrm{~h}^{-1}$. Significantly lower dehydrogenase activity was recorded in the treatment of pendimethalin @ $1000 \mathrm{~g} \mathrm{ha}^{-1}$ (PE) $f b$ halosulfuron-methyl @ $90 \mathrm{~g} \mathrm{ha}^{-1}$ (PoE), however, this treatment was at par with the treatments of pre and post emergence application of herbicides $\left(\mathrm{T}_{3}, \mathrm{~T}_{4}\right.$ and $\mathrm{T}_{6}$ to $\left.\mathrm{T}_{10}\right)$.

The per cent decrease in the dehydrogenase activity at harvest was $14.79 \%, 30.15 \%$ and 32. 57 to $35.70 \%$ in weed free treatment (two hand weeding), weedy check $\left(\mathrm{T}_{1}\right)$ and treatments of pre and post emergence herbicides $\left(T_{3}\right.$ to $\left.T_{10}\right)$, respectively over the initial value of $19.8 \mu \mathrm{g}$ TPF $\mathrm{g}^{-1}$ soil $24 \mathrm{~h}^{-1}$. The decrease in the dehydrogenase activity with the application of pre and post emergence herbicides was also reported by Nadiger et al., (2013), Inalli et al., (2014) and Abbas et al., (2015).

Among the herbicide treatments, the detrimental effect of pre and post emergence herbicides on periodiocal soil dehydrogenase activity was in the order of pendimethalin(PE) $f b$ 2,4 D ethyl ester (PoE) $>$ atrazine (PE) $f b$ 2,4 D ethyl ester (PoE) $>$ atazine (PE) $f b$ halosulfuron methyl $(\mathrm{PoE})>$ tembotrione $(\mathrm{PoE})>$ pendimethalin (PE) $f b$ halosulfuronmethyl $(\mathrm{PoE})=$ halosulfuron-methyl $(\mathrm{PoE})>$ pendimethalin $(\mathrm{PE}) f b$ tembotrione $(\mathrm{PoE})>$ 2,4 D ethyl ester (PoE). 
Table.1 Dehydrogenase activity in soil as influenced by application of herbicides

\begin{tabular}{|c|c|c|c|c|c|c|c|}
\hline \multirow[t]{2}{*}{ Sr. No } & \multirow[t]{2}{*}{ Treatments } & \multicolumn{6}{|c|}{ Dehydrogenase $\left(\mu \mathrm{g}\right.$ TPF $\mathrm{g}^{-1}$ soil $\left.24 \mathrm{~h}^{-1}\right)$} \\
\hline & & 7 DAS & 15 DAS & 21 DAS & 30 DAS & 45 DAS & $\begin{array}{c}\text { At } \\
\text { harvest }\end{array}$ \\
\hline 1. & Weedy & $17.58^{b}$ & $17.49^{\mathrm{bc}}$ & $16.49^{b}$ & $16.42^{b}$ & $15.35^{\mathrm{b}}$ & $13.83^{\mathrm{b}}$ \\
\hline 2. & Weed free (two hand weedings) & $18.93^{\mathrm{a}}$ & $21.61^{\mathrm{a}}$ & $23.34^{\mathrm{a}}$ & $22.74^{\mathrm{a}}$ & $21.57^{\mathrm{a}}$ & $16.87^{\mathrm{a}}$ \\
\hline 3. & $\begin{array}{l}\text { Atrazine @ } 1000 \mathrm{~g} \mathrm{ha}^{-1}(\mathrm{PE}) \text { fbhalosulfuron } \\
\text { methyl @ } 90 \mathrm{~g} \mathrm{ha}^{-1}(\mathrm{PoE})\end{array}$ & $17.65^{\mathrm{b}}$ & $16.88^{\mathrm{c}}$ & $13.73^{\mathrm{c}}$ & $13.13^{\mathrm{c}}$ & $12.17^{\mathrm{c}}$ & $12.97^{\mathrm{bc}}$ \\
\hline 4. & $\begin{array}{l}\text { Atrazine @ } 1000 \mathrm{~g} \mathrm{ha}^{-1} \text { (PE) fb 2,4 D ethyl } \\
\text { ester @ } 1000 \mathrm{~g} \mathrm{ha}^{-1}(\mathrm{PoE})\end{array}$ & $17.73^{\mathrm{b}}$ & $16.83^{\mathrm{c}}$ & $13.52^{\mathrm{c}}$ & $13.09^{c}$ & $12.06^{\mathrm{c}}$ & $13.03^{\mathrm{bc}}$ \\
\hline 5. & $\begin{array}{l}\text { Pendimethalin@1000 g ha }(\mathrm{PE}) \mathrm{fb} \\
\text { halosulfuron-methyl @ } 90 \mathrm{~g} \mathrm{ha}^{-1}(\mathrm{PoE})\end{array}$ & $17.75^{\mathrm{b}}$ & $16.62^{\mathrm{c}}$ & $13.66^{\mathrm{c}}$ & $13.15^{\mathrm{c}}$ & $12.43^{\mathrm{c}}$ & $12.73^{\mathrm{c}}$ \\
\hline 6. & $\begin{array}{l}\text { Pendimethalin @ } 1000 \mathrm{~g} \\
\mathrm{ha}^{-1} \text { (PE) } f b \text { tembotrione @ } 120 \mathrm{~g} \mathrm{ha}^{-1}(\mathrm{PoE})\end{array}$ & $17.77^{\mathrm{b}}$ & $16.62^{c}$ & $14.13^{\mathrm{c}}$ & $13.49^{c}$ & $12.62^{\mathrm{c}}$ & $12.74^{\mathrm{c}}$ \\
\hline 7. & $\begin{array}{l}\text { Pendimethalin@1000 g ha }{ }^{-1}(\mathrm{PE}) f b 2,4 \mathrm{D} \\
\text { ethyl ester@1000 } \mathrm{g} \mathrm{ha}^{-1}(\mathrm{PoE})\end{array}$ & $17.95^{\mathrm{b}}$ & $16.64^{\mathrm{c}}$ & $13.94^{\mathrm{c}}$ & $12.93^{\mathrm{c}}$ & $11.74^{\mathrm{c}}$ & $12.75^{\mathrm{c}}$ \\
\hline 8. & Halosulfuron-methyl @ $90 \mathrm{~g} \mathrm{ha}^{-1}(\mathrm{PoE})$ & $17.97^{\mathrm{b}}$ & $17.72^{\mathrm{bc}}$ & $14.99^{\mathrm{bc}}$ & $14.55^{\mathrm{c}}$ & $12.43^{\mathrm{c}}$ & $13.10^{\mathrm{bc}}$ \\
\hline 9. & Tembotrione@120 $\mathrm{g} \mathrm{ha}^{-1}(\mathrm{PoE})$ & $17.96^{\mathrm{b}}$ & $18.02^{b}$ & $15.40^{\mathrm{bc}}$ & $14.45^{\mathrm{c}}$ & $12.18^{\mathrm{c}}$ & $13.35^{\mathrm{bc}}$ \\
\hline 10. & 2,4 D ethyl ester @ $1000 \mathrm{~g} \mathrm{ha}^{-1}(\mathrm{PoE})$ & $18.11^{\mathrm{b}}$ & $17.91^{\mathrm{bc}}$ & $14.75^{\mathrm{c}}$ & $14.30^{\mathrm{c}}$ & $12.81^{\mathrm{c}}$ & $13.25^{\mathrm{bc}}$ \\
\hline & $\mathrm{SE}(\mathrm{m}) \pm$ & 0.18 & 0.36 & 0.52 & 0.53 & 0.46 & 0.35 \\
\hline & $\mathrm{CD}$ at $5 \%$ & 0.56 & 1.08 & 1.57 & 1.60 & 1.39 & 1.06 \\
\hline
\end{tabular}

Table.2 Urease activity in soil as influenced by application of herbicides

\begin{tabular}{|c|c|c|c|c|c|c|c|}
\hline \multirow{2}{*}{$\begin{array}{l}\text { Sr. } \\
\text { No. }\end{array}$} & \multirow[t]{2}{*}{ Treatments } & \multicolumn{6}{|c|}{ Urease activity $\left(\mathrm{mg} \mathrm{NH}_{4}-\mathrm{N} 100 \mathrm{~g}\right.$ soil h$\left.^{-1}\right)$} \\
\hline & & 7 DAS & 15 DAS & 21 DAS & 30 DAS & 45 DAS & At harvest \\
\hline 1. & Weedy & $28.29^{c}$ & $27.17^{\mathrm{bc}}$ & $25.21^{\mathrm{b}}$ & $27.75^{\mathrm{b}}$ & $27.41^{\mathrm{b}}$ & $24.98^{\mathrm{b}}$ \\
\hline 2. & Weed free (two hand weedings) & $29.66^{\mathrm{a}}$ & $31.27^{\mathrm{a}}$ & $31.49^{\mathrm{a}}$ & $33.38^{\mathrm{a}}$ & $33.31^{\mathrm{a}}$ & $27.63^{\mathrm{a}}$ \\
\hline 3. & $\begin{array}{l}\text { Atrazine @ } 1000 \mathrm{~g} \mathrm{ha}^{-1}(\mathrm{PE}) \\
\mathrm{fb} \text { halosulfuron methyl @ } 90 \mathrm{~g} \\
\mathrm{ha}^{-1}(\mathrm{PoE})\end{array}$ & $28.48^{\mathrm{bc}}$ & $26.46^{\mathrm{c}}$ & $22.42^{\text {cd }}$ & $24.49^{\text {cd }}$ & $24.13^{\mathrm{c}}$ & $23.73^{\mathrm{c}}$ \\
\hline 4. & $\begin{array}{l}\text { Atrazine @ } 1000 \mathrm{~g} \mathrm{ha}^{-1}(\mathrm{PE}) \mathrm{fb} \\
2,4 \mathrm{D} \text { ethyl ester @ } 1000 \mathrm{~g} \mathrm{ha}^{-1} \\
\text { (PoE) }\end{array}$ & $28.48^{\mathrm{bc}}$ & $26.51^{\mathrm{c}}$ & $22.26^{\mathrm{d}}$ & $24.40^{\mathrm{d}}$ & $24.09^{\mathrm{d}}$ & $23.74^{\mathrm{c}}$ \\
\hline 5. & $\begin{array}{l}\text { Pendimethalin @ } 1000 \mathrm{~g} \mathrm{ha}^{-1} \\
\text { (PE) } f b \text { halosulfuron-methyl @ } \\
90 \mathrm{~g} \mathrm{ha}^{-1} \text { (PoE) }\end{array}$ & $28.47^{\mathrm{bc}}$ & $26.38^{\mathrm{c}}$ & $22.36^{\mathrm{cd}}$ & $24.50^{\mathrm{cd}}$ & $24.05^{\mathrm{d}}$ & $23.60^{\mathrm{c}}$ \\
\hline 6. & $\begin{array}{l}\text { Pendimethalin@ } 1000 \mathrm{~g} \mathrm{ha}^{-1} \\
\text { (PE) fb tembotrione @ } 120 \mathrm{~g} \mathrm{ha}^{-1} \\
\text { (PoE) }\end{array}$ & $28.47^{\mathrm{bc}}$ & $26.32^{c}$ & $22.64^{\text {cd }}$ & $24.72^{\text {cd }}$ & $24.01^{\mathrm{d}}$ & $23.57^{\mathrm{c}}$ \\
\hline 7. & $\begin{array}{l}\text { Pendimethalin @ } 1000 \mathrm{~g} \mathrm{ha}^{-1} \\
\text { (PE) fb 2,4 D ethyl ester @ } 1000 \\
\mathrm{~g} \mathrm{ha}^{-1} \text { (PoE) }\end{array}$ & $28.48^{\mathrm{bc}}$ & $26.31^{\mathrm{c}}$ & $22.61^{\mathrm{cd}}$ & $24.69^{\text {cd }}$ & $24.10^{\text {cd }}$ & $23.49^{\mathrm{c}}$ \\
\hline 8. & $\begin{array}{l}\text { Halosulfuron-methyl @ } 90 \mathrm{~g} \mathrm{ha}^{-1} \\
\text { (PoE) }\end{array}$ & $28.92^{b}$ & $27.74^{\mathrm{b}}$ & $23.66^{c}$ & $25.75^{\mathrm{cd}}$ & $25.17^{\mathrm{cd}}$ & $23.93^{\mathrm{c}}$ \\
\hline 9. & Tembotrione@ $120 \mathrm{~g} \mathrm{ha}^{-1}(\mathrm{PoE})$ & $28.85^{\mathrm{b}}$ & $27.71^{\mathrm{b}}$ & $23.89^{\mathrm{bc}}$ & $25.92^{c}$ & $25.25^{\mathrm{c}}$ & $23.98^{\mathrm{c}}$ \\
\hline 10. & $\begin{array}{l}2,4 \text { D ethyl ester@1000 g ha }{ }^{-1} \\
\text { (PoE) }\end{array}$ & $28.87^{b}$ & $27.71^{b}$ & $23.29^{\mathrm{cd}}$ & $25.70^{\mathrm{cd}}$ & $25.17^{\mathrm{cd}}$ & $23.95^{\mathrm{c}}$ \\
\hline & $\mathrm{SE}(\mathrm{m}) \pm$ & 0.18 & 0.33 & 0.46 & 0.48 & 0.38 & 0.23 \\
\hline & $\mathrm{CD}$ at $5 \%$ & 0.55 & 1.00 & 1.38 & 1.43 & 1.15 & 0.71 \\
\hline
\end{tabular}


The decrease in soil dehydrogenase enzyme activity might be associated with an inhibition of microbial population which was one of the source of soil dehydrogenase enzyme on disintegration of microbial cells. Similarly, there might be binding of active site of dehydrogenase enzyme with pre and post emergence herbicides (Latha and Gopal 2010, Nadiger et al., 2013).

\section{Urease activity}

The periodical urease activity in soil was significantly influenced at $7,15,21,30$ and 45 days after application by pre and post emergence herbicides during the field experiment. Significantly higher urease activity of $29.66,31.37,31.49,33.38$ and 33. $31 \mathrm{mg} \mathrm{NH}_{4}-\mathrm{N} 100 \mathrm{~g}$ soil h${ }^{-1}$ was recorded in the weed free (two hand weeding) treatment $\left(\mathrm{T}_{2}\right)$ at $7,15,21,30$ and 45 DAS, respectively, as compared to rest of the treatments. The increase of $15.25 \%$ at 45 DAS was observed in the periodical urease activity in $\mathrm{T}_{2}$ treatment.

The periodical urease activity in soil was decreased with advanced period of field experimentation in the treatment of weedy check $\left(\mathrm{T}_{1}\right)$ and the treatments of pre and post emergence herbicides application $\left(\mathrm{T}_{3}\right.$ to $\left.\mathrm{T}_{10}\right)$ except at 7 DAS the periodical urease activity was maintained as initial value in the treatment of halosulfuron-methyl @ $90 \mathrm{~g} \mathrm{ha}^{-1}$ as a post emergence $\left(T_{8}\right)$. The periodical urease activity at 45 DAS in the treatment of weedy check $\left(\mathrm{T}_{1}\right)$ was $27.41 \mathrm{mg} \mathrm{NH} \mathrm{NH}_{4}-\mathrm{N} 100$ $\mathrm{g}$ soil $\mathrm{h}^{-1}$ with $5.15 \%$ reduction over the initial value $\left(28.9 \mathrm{mg} \mathrm{NH}_{4}-\mathrm{N} 100 \mathrm{~g}\right.$ soil h${ }^{-1}$ ). The periodical urease activity at 45 DAS was ranged between 24.01 to $25.25 \mathrm{mg} \mathrm{NH}_{4}-\mathrm{N}$ $100 \mathrm{~g}$ soil $\mathrm{h}^{-1}$ in the treatments of pre and post emergence herbicides application $\left(\mathrm{T}_{3}\right.$ to $\mathrm{T}_{10}$ ) with 12.62 to $16.92 \%$ reduction over the initial value.
The urease activity was significantly higher (27. $63 \mathrm{mg} \mathrm{NH}$-N $100 \mathrm{~g}$ soil h${ }^{-1}$ ) in the weed free treatment (two hand weeding) at harvest of sweet corn. It was followed by the treatment of weedy check $\left(\mathrm{T}_{1}\right)$, which recorded the urease activity $24.98 \mathrm{mg} \mathrm{NH}_{4}-\mathrm{N}$ $100 \mathrm{~g}$ soil $\mathrm{h}^{-1}$. The per cent decrease in the urease activity was $4.39 \%, 13.56 \%$ and 17 . 02 to $17.88 \%$ in the weed free treatment (two hand weeding), weedy check $\left(\mathrm{T}_{1}\right)$ and treatments of pre and post emergence herbicides $\left(T_{3}\right.$ to $\left.T_{10}\right)$, respectively over the initial value of $28.9 \mathrm{mg} \mathrm{NH}_{4}-\mathrm{N} 100 \mathrm{~g}_{\text {soil }} \mathrm{h}^{-1}$. The decrease in urease activity with the application of pre and post emergence herbicides was also reported by Sireesha et al., (2012), Abbas et al., (2014) and Abbas et al., (2015).

The results revealed that an application of tembotrione@120 $\mathrm{g} \mathrm{ha}^{-1}$ as post emergence herbicide $\left(\mathrm{T}_{9}\right)$ has less adverse effect on periodical urease activity in soil than the other herbicides treatments under study. However, the treatment $\mathrm{T}_{9}$ was statistically at par with treatment atrazine@1000 g ha ${ }^{-1}$ as pre emergence fbhalosulfuron methyl @ $90 \mathrm{~g} \mathrm{ha}^{-1}$ as post emergence $\left(\mathrm{T}_{3}\right)$, pendimethalin @ 1000 $\mathrm{g} \mathrm{ha}^{-1}$ as pre emergence $f b$ 2,4 D ethyl ester @ $1000 \mathrm{~g} \mathrm{ha}^{-1}$ as post emergence $\left(\mathrm{T}_{7}\right)$, Halosulfuron-methyl @ $90 \mathrm{~g} \mathrm{ha}^{-1}$ as post emergence $\left(\mathrm{T}_{8}\right)$ and 2,4 D ethyl ester @ 1000 $\mathrm{g} \mathrm{ha}^{-1}$ as post emergence $\left(\mathrm{T}_{10}\right)$.

The decreased urease enzyme activity with an application of pre and post emergence herbicides might be associated with the increased application of herbicides leads to increased chemical concentrations in soil, altered soil reactions, adverse effects on non target organisms, alter the biological equilibrium in the soil, lower the microbial population and hence lower enzyme activity. The results are in conformity with the findings of Latha and Gopal (2010), Kavitha et al., (2011) and Abbas et al., (2015). 
It is concluded that, among the herbicide treatments, the minimum detrimental effect of herbicides on dehydrogenase and urease activity was observed in the treatment of tembotrione@120 $\mathrm{g} \mathrm{ha}^{-1}$ as post emergence herbicide $\left(\mathrm{T}_{9}\right)$ at $7,15,21,30,45 \mathrm{DAS}$ and at harvest.

\section{Acknowledgement}

The authors are grateful to the I/c. Professor, Department of Agronomy, College of Agriculture, Dhule for providing necessary facilities for conduct of the experiment.

\section{References}

Abbas, Z., Akmal, M., Khan, K. S. and Hassan, F. (2014) Effect of Bructril Super (Bromoxynil) herbicide on soil microbial biomass and bacterial population. Brazilian Archives of Biology and Technology 57(1), 9-14.

Abbas, Z., Akmal, M., Khan, K. S. and Hassan, F. (2015) Response of soil micro organisms and enzyme activity to application of bromoxynil under rainfed condition. International Journal of Agriculture Biology17, 305-312.

Bansal, O. P. (2015) Long term effects of organic manures (FYM, sewage sludge) amendments on soil enzymatic activities in an alluvial soil of Aligarh district: A 20 year study. Journal of Scientific Research in Allied Science 1, 135-145.

Beller, H.R., Spormann, A.M., Sharma, P.K., Cole, J.R. and Reinhard, M. (1996) Isolation and characterization of a novel toluene-degrading, sulfate-reducing bacterium. Applied and Environmental Microbiology 62, 1188-1196.

Casida, L.; Klein, D. and Santoro, T., (1964) Soil dehydrogenase activity. Soil Science 98, 371- 376.

Dey, P., Pratap, T., Singh V.P., Singh, R. and Singh, S.P. (2017) Weed management options for spring sweet corn. ISWS Golden Jubilee International Conference on "Weeds and Society: Challenges and Opportunities", ICAR-Directorate of Weed Research, Jabalpur, India during 21-24 November 2018: 297.

Davies, H.A and Greaves, M.P. (1981) Effects of some herbicides on soil enzyme activities. Weed Research21, 205-209.

Inalli, K., Aravindakumar, B. N., Geeta, G. S. and Babu, R. (2014) Effect of tank mixture herbicides on phytotoxicity, soil dehydrogenase activity and nutrient uptake by weeds in Maize. Trends in Biosciences7(14), 1839-1842.

Kavitha, M. P., Ganesaraja, V., Paulpand, V.K. and Subramanian, R. B. (2011) Rhizosphere enzyme activities as influenced by age of seedlings, weed management practices and humic acid application under system of rice intensification. Indian Journal of Agriculture Research45(2), 151-155.

Latha, P. C. and Gopal, H. (2010) Effect of herbicides on soil micro-organisms. Indian Journal of Weed Science, $42(3$ \& 4), 217-222.

Nadiger, S., Baboo, R. and Arvindkumar, B. N. (2013) Bioefficacy of pre emergence herbicides on weed management in maize. Karnataka Journal of Agriculture Science26(1), 17-19.

Sireesha, A., Rao, P. C., Ramalaxmi, C. S. and Swapna, G. (2012) Effect of pendimethalin and oxyfluorfen on soil enzyme activity. Journal of Crop and Weed8(1), 124-128.

Srinivasarao, C., Kundu, S., Grover, M., Manjunath, M., Sudhanshu, S. K., Patel, J. J., Singh, S. R., Singh, R. P., Patel, M. M., Ayyandar, A., and Soam, S. K. (2018) Effect of long term application of organic and inorganic fertilizers on soil microbial activities in semi-arid and subhumid rainfed agricultural systems. Tropical Ecology 59(1), 99-108.

Tabatabai, M.A. and Bremner, J.M. (1972) Assay of Urease activity in soil. Soil Biology Biochemistry 4, 479-487. 


\section{How to cite this article:}

Rathod, R. K., V. P. Bhalerao, P. B. Margal and Thakare, R. S. 2021. Soil Enzymes as Influenced by Pre and Post Emergence Herbicide in Sweet Corn Grown in Vertisols. Int.J.Curr.Microbiol.App.Sci. 10(01): 2787-2793. doi: https://doi.org/10.20546/ijcmas.2021.1001.322 